\title{
Henry George Cook
}

Canada's North, like so many other areas in the country, has a history of selectivity in regard to acknowledging its outstanding citizens: a few become household words "renowned around in story and song,"' while others, having served their generation, tend to slip away almost unnoticed. Of these latter, Henry George Cook, sometime Anglican bishop of Mackenzie, has to be a prime example: self-effacing, genuinely modest, but with a personal history that demands both recognition and commendation.

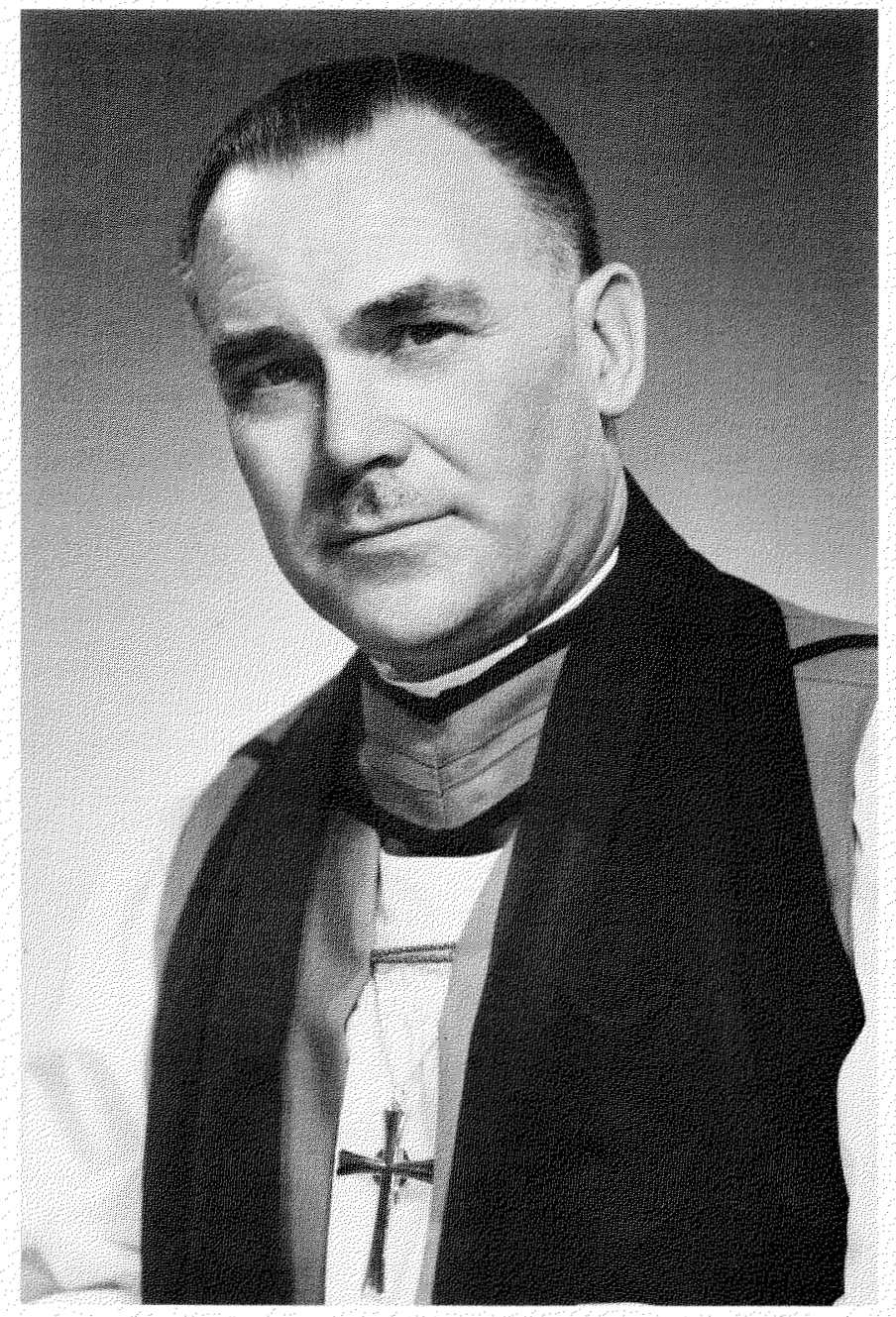

He was born in 1906 to Henry G. and Ada Cook in Walthamstow, England. His father served in the Royal Navy, later purchasing his release and immigrating with his family to Canada, where in 1913 they settled at Woodstock, Ontario. In his early years, Henry, Jr. (known most intimately as "Harry" to his friends) showed special interest in music, singing tenor in the church choir and playing the clarinet.

Cook consistently maintained a close relationship with his church, then called the Church of England in Canada, and through his associations there gradually developed a vocation to the sacred ministry. Even though the traditionally low stipend levels of the clergy in that day seemed to act as a deterrent, at the age of 23 Henry Cook embarked upon the study for the ministry.

This involved enrolment in Huron College (London, Ontario) and the University of Western Ontario as a special student, where he was awarded a degree in theology and a bachelor of arts degree. During his university days, Cook met Opal May Thompson, a fellow student who was later to become his wife and who shared with him his long ministry both in the North and in southern Canada. Opal Cook died early in 1987, having accomplished many years of faithful service under some primitive and rugged conditions.

Henry Cook began his ministry in 1935. Immediately he left eastern Canada for his first appointment, at Fort Smith, Northwest Territories. In those days, the Canadian northwest was not easily accessible, and the bishop of Athabasca had not yet visited the area of Mackenzie. Therefore he could give little advice to the young missionary going north for the first time. No sooner had Cook arrived in Fort Smith than he received further instructions by telegraph to take the mission at Fort Simpson. His bride, Opal, joined him at Fort Smith. Eventually they sailed for Fort Simpson on the river boat Distributor, the trip on Great Slave Lake taking eight days due to contrary winds.

Those were the days of wood-burning stoves, but it would seem that Fort Simpson proved to be a very pleasant as well as historic mission for this young missionary couple. Clerical duties included teaching school and, of course, the study of the Slavey language, used by the Indian population in that area. Visits were made to outside camps and each summer included a trip up the Liard River, during which Opal conducted church services - a custom that clergy wives throughout the North followed as part of their own special ministry.

The mission at Fort Simpson covered places farther down the Mackenzie River to Wrigley, Fort Norman and Fort Providence, journeys that in those days were lengthy and difficult. At the outbreak of World War II Henry Cook offered himself for chaplaincy service, but as there were no vacancies, he continued his ministry until 1940 , when his first furlough was permitted.

During the war the whole area was affected by the influence of the American Army, the establishment of a pipeline from Fort Norman through to the Yukon and air strip construction. At such times of development, with the arrival of so many non-northerners into isolated communities, all kinds of disruptions were possible. As a result the military authorities were only too pleased to invite the services of the Rev. Henry Cook for chaplaincy work and counselling, which he did as a part of his concerned ministry for all in the area.

By 1943, family concerns in eastern Canada were such that serious consideration needed to be given to accept a move to that part of the country. Bishop Rennison had been in the Mackenzie area and suggested that Cook consider a curacy for a time at St. Paul's Church, Bloor Street. After prayerful consideration, the move was made. One could hardly imagine a greater contrast than that between St. David's, Fort Simpson, and St. Paul's Church, Bloor Street. One of the obvious advantages of the move was that the huge congregation at St. Paul's was able to hear first-hand something of the missionary work undertaken on the frontiers of a Canadian church. Not long after arrival in 
Toronto, Bishop Rennison was elected to the See of the Diocese of Moosonee in northern Ontario, and he immediately invited Cook to work under his jurisdiction. His next mission was at St. Thomas' Church, Moose Factory. This entailed a principalship of the Bishop Horden Residential School, superintendent of the Bishop Newnham Hospital and a missioner across the Moose River at Moosonee. Henry Cook was later made archdeacon of James Bay.

In that era the foremost agency in introducing formal education to the native people of Canada was the church, namely the Anglican and Roman Catholic communions. The Anglican native residential schools were administered by the Indian School Administration, headquartered in Ottawa. In 1948 two superintendents of the ISA died within three months and the call came to Archdeacon Cook to assume the role as superintendent, based in Ottawa. This move took place in January 1949.

The move to Ottawa was to commence a 15-year ministry of superintendency over the Anglican mission schools in the provinces and the two territories. Under this administration, there were 20 residential schools and 5 mission hospitals. Canon Cook, as Henry was now appointed, was constantly on the move during these years, and according to unsolicited testimonials, his visits always had a particular pastoral dimension; concern for the children was paramount on his agenda.

With the progress of years, and the increased involvement of the federal government in northern affairs, it became impossible for the church's administration to meet the salary demands of both teachers and hostel supervisors. This was true for both churches and led eventually to the assumption of educational responsibility by the federal government. This was also true of the hospital situation in the North, and a gradual withdrawal of responsibilities for both education and health from the churches resulted in a greater government presence in the North and the gradual disappearance of the church agencies that for so long had served northern people.

After about a decade during which native leadership in various parts of Canada gave the church hostel enterprises a very poor press, it is noteworthy that more recently there has been an obvious amelioration in attitude. Certainly it was church hostels, despite their obvious drawbacks, that enabled the present leadership of native people to have both an excellent grasp of the English language and other gifts preparing them for leadership, albeit sometimes at the cost of a close association with their own native culture.

Prior to the actual closure of church hostels in the Mackenzie area during the autumn of 1962, an election took place for a bishop suffragan to assist the Rt. Rev. D.B. Marsh, bishop of the Arctic. At that election Canon Henry Cook received the required amount of votes. On 6 January 1961 the Rev. Canon Henry George Cook was consecrated as the first bishop suffragan of the Diocese of the Arctic. The new bishop's jurisdiction centred mainly in the Western Arctic and throughout the Mackenzie River communities down to the Arctic Coast. These areas were considerably different in ethos and history from the largely Indian communities down the Mackenzie River. Difficulties arose in respect to a common approach for the developing life of the diocese. The end result was that the Mackenzie district, which encompassed all communities around Great Slave Lake down to Tuktoyaktuk and including Sacks Harbour, was placed under the spiritual jurisdiction of the diocese of Athabasca, with Bishop Cook maintaining specific responsibilities for the Mackenzie. Later, the Mackenzie district was made an episcopal district with independence from all other dioceses and solely responsible to the Metropolitan of Rupert's Land. The situation continued until the retirement of Bishop Cook in 1974 at the age of 68 .

Bishop and Mrs. Cook, however, were not finished with the North. With the bishop's keen interest in the history of the region, he was invited by Commissioner Stuart Hodgson to assist in the setting up of what was to become the Prince of Wales Northern Heritage Centre. This project strongly appealed to the bishop, and it is significant that within this imposing structure in the capital of the Northwest Territories, the archival section bears the bishop's name as a tribute to his work in completing this important project. The Prince of Wales Northern Heritage Centre was opened in 1979. Shortly thereafter the Cooks finally retired to Stittsville, Ontario, where the bishop presently lives.

The later history of the church's life, together with the development of missions down the Mackenzie area, would not be complete without an acknowledgement of the devotion, commitment and concerned oversight expressed through the life and ministry of Henry George Cook, bishop of Mackenzie.

John R. Sperry

Anglican Bishop of the Arctic

1 Dakota Court

Yellowknife, Northwest Territories

Canada

$\mathrm{X} 1 \mathrm{~A} 2 \mathrm{~A} 4$ 